\title{
Geochemical Database of Feed Coal and Coal Combustion Products (CCPs) from Five Power Plants in the United States
}

By Ronald H. Affolter, ${ }^{1}$ Steve Groves, 'William J. Betterton, ${ }^{1}$ William Benzel, ${ }^{1}$ Kelly L. Conrad, ${ }^{1}$ Sharon M. Swanson, ${ }^{2}$ Leslie F. Ruppert, ${ }^{2}$ James G. Clough, ${ }^{3}$ Harvey E. Belkin, ${ }^{2}$ Allan Kolker, ${ }^{2}$ and James C. Hower ${ }^{4}$

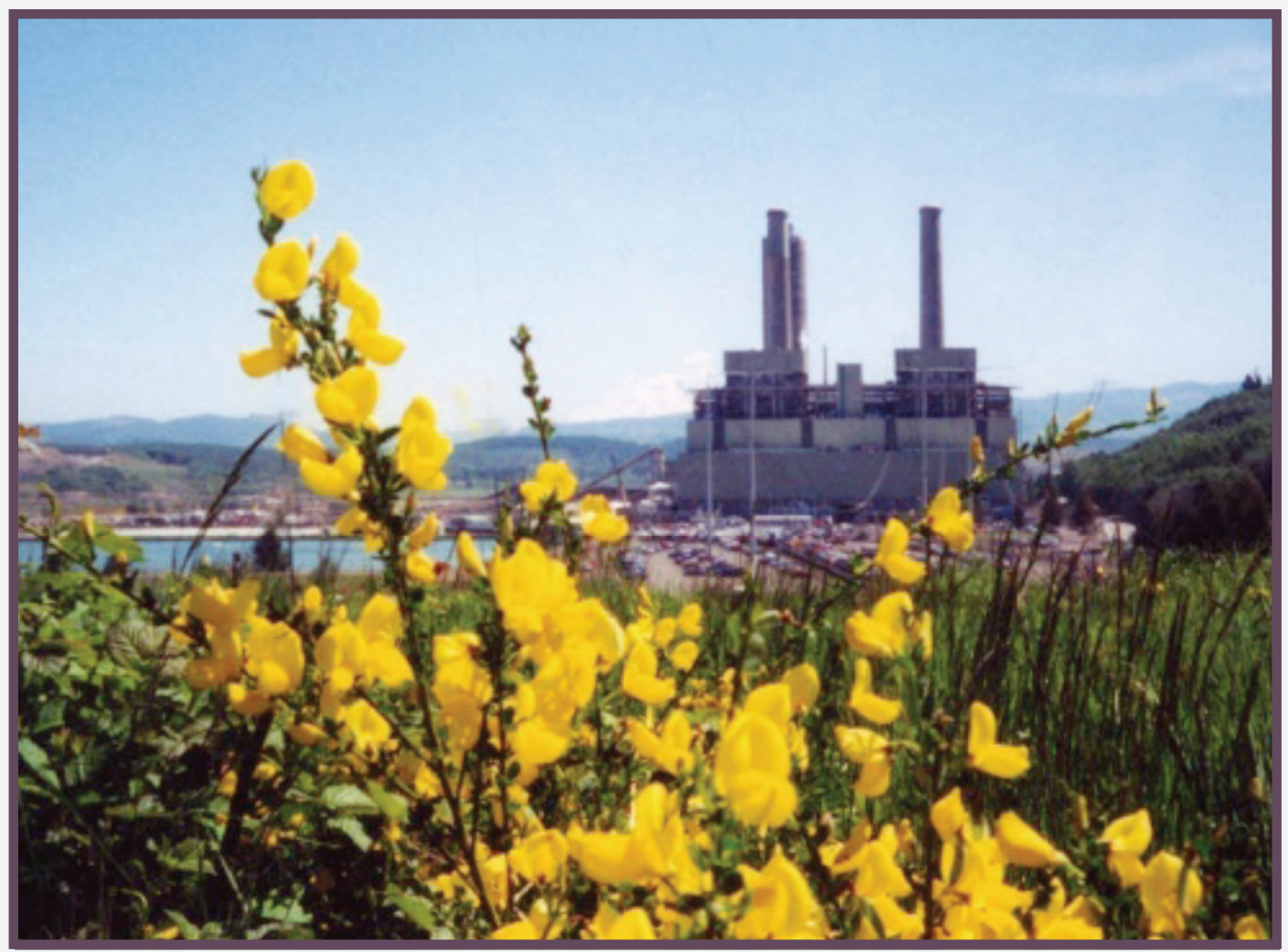

Pamphlet to accompany

Data Series 635

U.S. Department of the Interior

U.S. Geological Survey 


\title{
U.S. Department of the Interior \\ KEN SALAZAR, Secretary
}

\section{U.S. Geological Survey \\ Marcia K. McNutt, Director}

\section{U.S. Geological Survey, Reston, Virginia: 2011}

\author{
About USGS Products \\ For product and ordering information: \\ World Wide Web: http://www.usgs.gov/pubprod \\ Telephone: 1-888-ASK-USGS \\ For more information on the USGS - the Federal source for science about the Earth, its natural and \\ living resources, natural hazards, and the environment: \\ World Wide Web: http://www.usgs.gov \\ Telephone: 1-888-ASK-USGS
}

\section{About this Product}

Publishing support provided by

Denver Science Publishing Network

For more information concerning this publication, contact:

Center Director, USGS Central Energy Resources Science Center

Box 25046, Mail stop 939

Denver, C0 80225

(303) 236-7775

or visit the Central Energy Resources Science Center Web site at: http://energy.cr.usgs.gov

Suggested citation:

Affolter, R.H., Groves, Steve, Betterton, W.J., Benzel, William, Conrad, K.L., Swanson, S.M., Ruppert L.F., Clough J.G., Belkin, H.E., Kolker, Allan, and Hower, J.C., 2011, Geochemical database of feed coal and coal combustion products (CCPs) from five power plants in the United States: U.S. Geological Survey Data Series 635, pamphlet, 19 p.

Any use of trade, product, or firm names is for descriptive purposes only and does not imply endorsement by the U.S. Government.

Although this report is in the public domain, permission must be secured from the individual copyright owners to reproduce any copyrighted materials contained within this report.

ISBN 978-1-4113-3268-3

Cover: Photograph of a coal-fired power plant in the northwestern United States. Photograph by Ronald H. Affolter. 


\section{Contents}

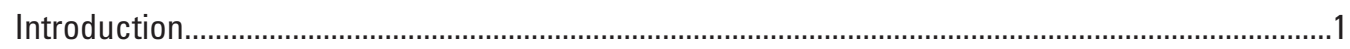

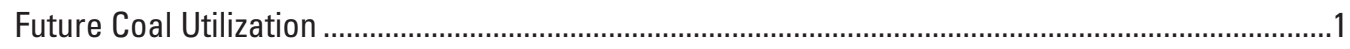

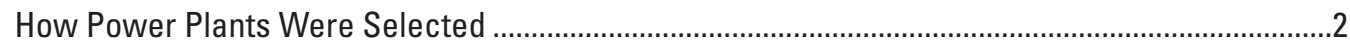

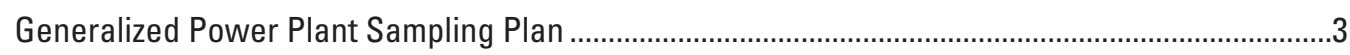

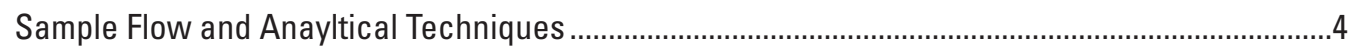

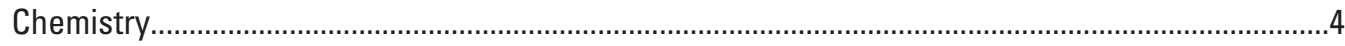

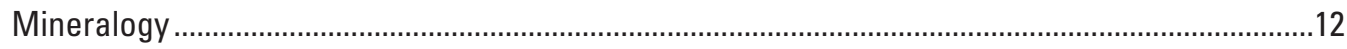

Sample Preparation for X-Ray Diffraction Analysis..............................................................12

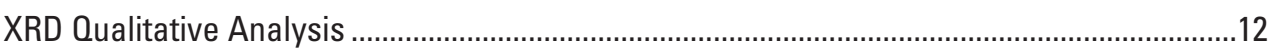

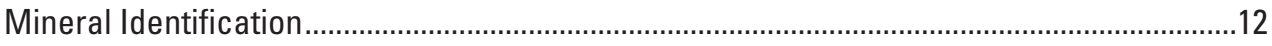

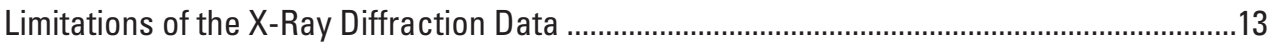

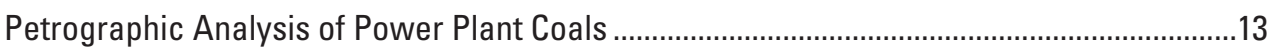

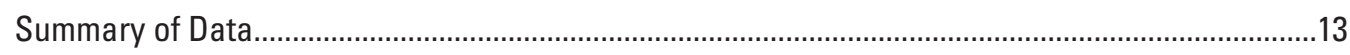

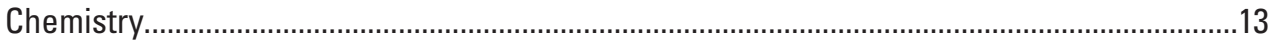

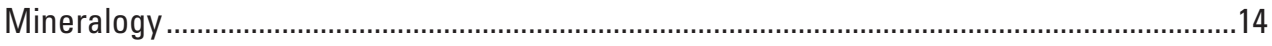

Selected Coal Utilization References ..........................................................................................

Description of Power Plant Data Series .................................................................................

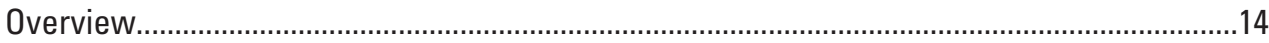

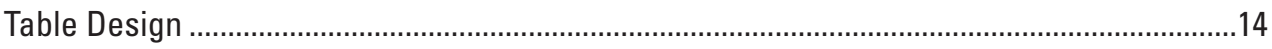

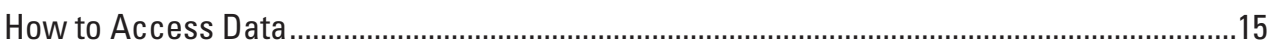

Summary of Data Collected and Included in this Data Series ......................................................16

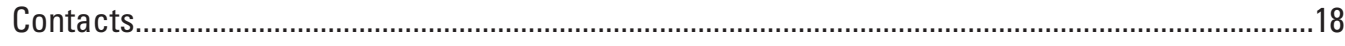

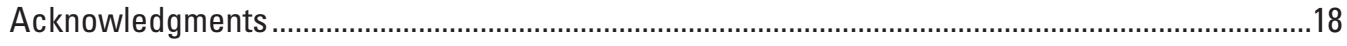

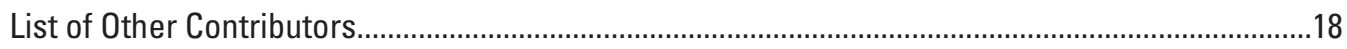

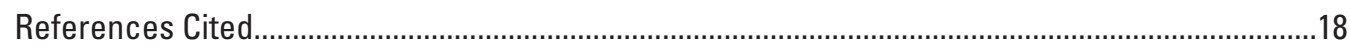

\section{Figures}

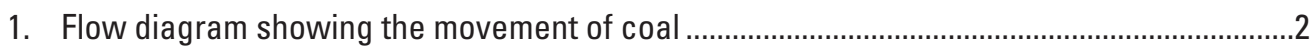

2. Diagram of possible power-plant sample collection sites........................................................

3-7. Diagram showing the flow of coal through the:

3. Alaska power plant and location of sample collections sites..........................................5

4. Indiana power plant and location of sample collections sites ..........................................

5. New Mexico power plant and location of sample collections sites .................................

6. Ohio power plant and location of sample collections sites..............................................

7. Wyoming power plant and location of sample collections sites .....................................

8. Diagram showing flow of samples collected at power plants and types of analyses..........11

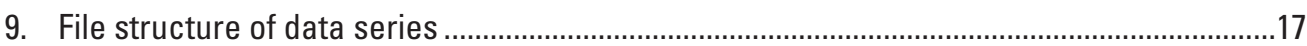

\section{Tables}

1. Power plant location, feed coal basin, age, stratigraphic unit, utilized feed coal, database sample prefix, and number of samples ..........................................................................

2. Power plant location, type of sample, sample abbreviation, and number of samples collected for current study. 


\title{
Geochemical Database of Feed Coal and Coal Combustion Products (CCPs) from Five Power Plants in the United States
}

\author{
By Ronald H. Affolter,' Steve Groves, 'William J. Betterton, ' William Benzel,' Kelly L. Conrad, ${ }^{1}$ \\ Sharon M. Swanson, ${ }^{2}$ Leslie F. Ruppert, ${ }^{2}$ James G. Clough, ${ }^{3}$ Harvey E. Belkin, ${ }^{2}$ Allan Kolker, ${ }^{2}$ \\ and James C. Hower ${ }^{4}$
}

\section{Introduction}

The principal mission of the U.S. Geological Survey (USGS) Energy Resources Program (ERP) is to (1) understand the processes critical to the formation, accumulation, occurrence, and alteration of geologically based energy resources; (2) conduct scientifically robust assessments of those resources; and (3) study the impacts of energy resource occurrence and (or) their production and use on both the environment and human health. The ERP promotes and supports research resulting in original, geology-based, non-biased energy information products for policy and decision makers, land and resource managers, other Federal and State agencies, the domestic energy industry, foreign governments, nongovernmental groups, and academia. Investigations include research on the geology of oil, gas, and coal, and the impacts associated with energy resource occurrence, production, quality, and utilization. The ERP's focus on coal is to support investigations into current issues pertaining to coal production, beneficiation and (or) conversion, and the environmental impact of the coal combustion process and coal combustion products (CCPs). To accomplish these studies, the USGS combines its activities with other organizations to address domestic and international issues that relate to the development and use of energy resources.

\section{Future Coal Utilization}

Coal is a complex combustible rock made up of organic and inorganic mineral components containing many elements. During combustion, the elements are redistributed as a result of high temperatures into new gaseous and solid phases (USGS, 2001, 2002). Particle size, coal rank, amount of ash, coal chemistry, mineralogy, and petrology are important variables controlling the combustion process and their effects on the environment. It is also a widely accepted fact that the environmental "footprint" of coal utilization will have to continue to be reduced in the future. One of the basic building blocks to accomplish this goal is the development of sound databases that document the relation between geological controls on coal quality and the resultant CCPs. An integrated approach to this type of coal quality work-referred to as a "cradle to grave" approach-focuses on more than one aspect of the coal, such as how and (or) where different coal quality characteristics form and what happens to them through the process of mining, production, transport, utilization, and waste disposal. This approach allows the development of better predictive models of the fate of coal combustion-derived elements in the biosphere.

Coal quality, composition of stack emissions, and CCPs have become major environmental concerns as the rate of coal utilization increases nationally. With increasing emphasis on environmental issues, information on the quality of coal, which includes ash yield, sulfur content, and caloric value, as well as major-, minor-, and trace-element content, has become as important as information on the quantity of the resource. Therefore, it is becoming increasingly important to determine how these elements are distributed in the feed coal, the resulting changes in composition as coal is processed, and the chemical composition of the CCPs. The determination of elements in feed coal is important because the content, distribution, and behavior of elements during and after combustion depend in large part on the content and distribution of trace elements in the feed coal (fig. 1). With an adequate amount

\footnotetext{
${ }^{1}$ Central Energy Resources Science Center, Denver, Colo.

${ }^{2}$ Eastern Energy Resources Science Center, Reston, Va.

${ }^{3}$ Alaska Division of Geological and Geophysical Surveys, Fairbanks, Alaska.

${ }^{4}$ University of Kentucky Center for Applied Energy Research, Lexington, Ky.
} 


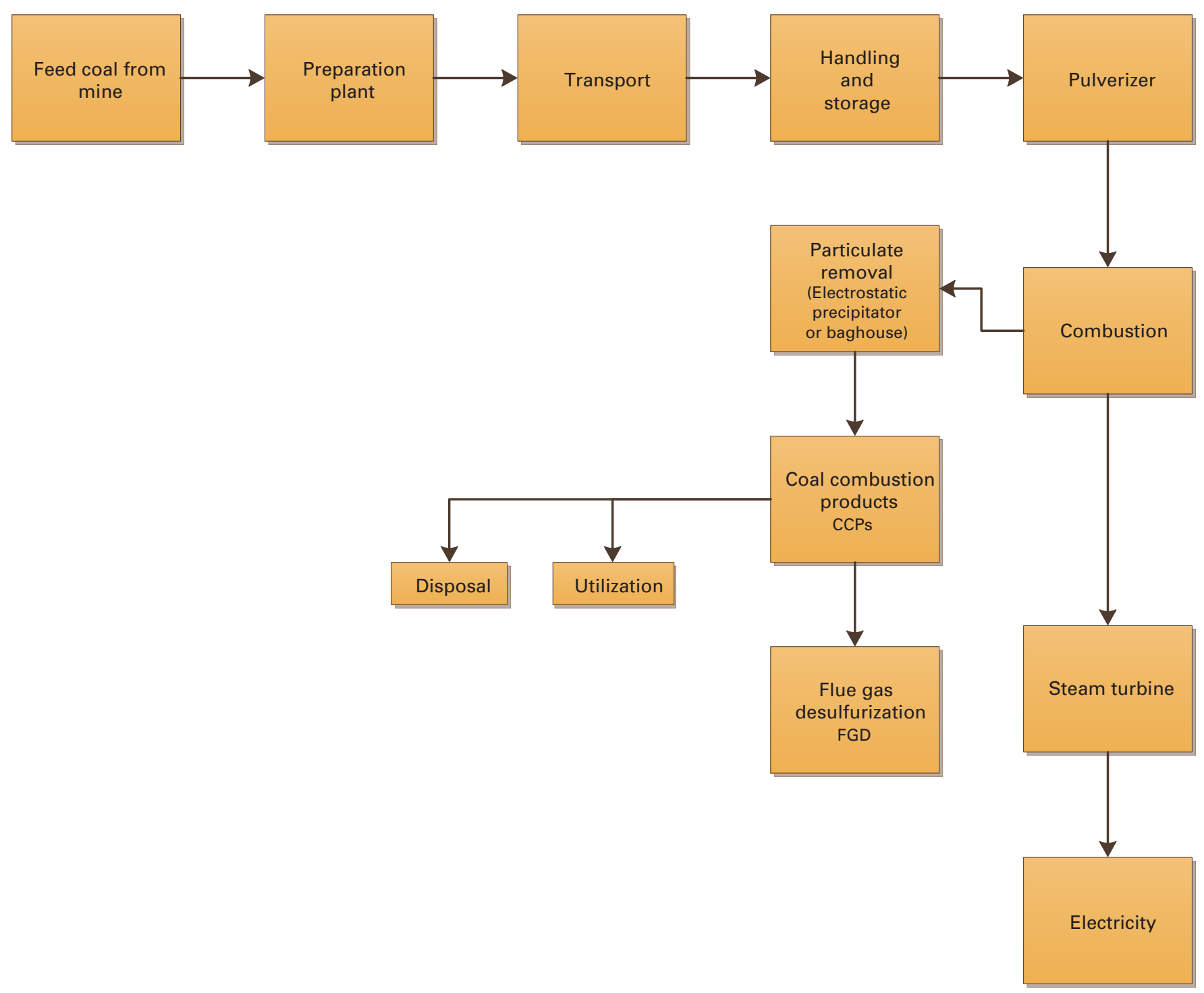

Figure 1. Flow diagram showing the movement of coal from the mine to the generation of electricity. Coal quality may impact any point in this flow and ultimately affects the quality of the coal combustion products (CCPs) and flue gas desulfurization (FGD) process. Modified from Skorupska, 1993.

of data from these studies, general predictive models can be developed so that issues like ash disposal and CCP utilization could be addressed with greater accuracy. This type of research fosters a fuller understanding of the fate and partitioning of elements during coal combustion, and leads to data that can be used to more accurately evaluate how coal-quality parameters affect air emissions and waste-disposal efforts. Past studies on the chemistry, mineralogy, and petrology of CCPs (for example, Grossman and others, 1988; Skorupska and Marsh, 1989; Skorupska, 1993; Karayığıt and others, 2001; Goodarzi, 2002; Sheetz, 2004; and Goodarzi, 2005) has shown how important this knowledge is to an understanding of the fate and partitioning of elements during the coal-combustion process. Therefore this compilation of power-plant data attempts to add to the knowledge and better understanding of the coal utilization process.

\section{How Power Plants Were Selected}

The initial goal of this study is to follow the flow of coal through a power plant, with emphasis on the distribution of element and mineral contents between the feed coal and various CCPs (economizer ash, fly ash, and bottom ash).

Coal-fired power plants are highly complex systems. The type of plants chosen for this study are commonly referred to as pulverized coal (PC)-fired plants, where the coal is crushed to a fine powder in a pulverizer in order to increase the surface area for injection into a boiler where it burns at temperatures around $1400^{\circ} \mathrm{C}$. This produces steam that turns turbines to produce electricity. The resultant CCPs that are generated from the burnt coal are captured in bag houses or electrostatic precipitators for disposal or future utilization. Most of these 


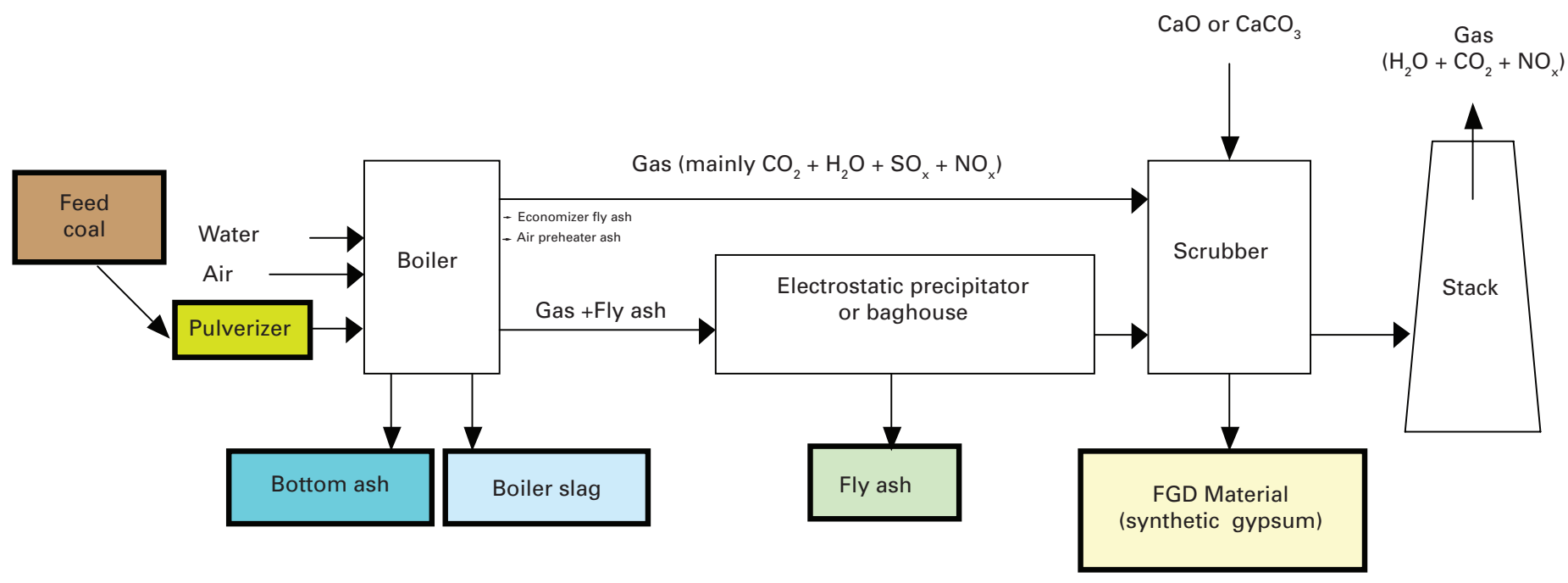

Figure 2. Simplified diagram of possible power-plant sample collection sites with a generalized flue gas desulfurization (FGD) process based on lime $(\mathrm{CaO})$ or limestone $\left(\mathrm{CaCO}_{3}\right)$. Modified from figure 2, U.S. Geological Survey Fact Sheet FS-076-01.

Table 1. Power plant location, feed coal basin, age, stratigraphic unit, utilized feed coal, database sample prefix, and number of samples.

\begin{tabular}{|c|c|c|c|c|c|c|}
\hline $\begin{array}{l}\text { Power plant } \\
\text { location }\end{array}$ & $\begin{array}{c}\text { Feed } \\
\text { coal basin }\end{array}$ & Age & $\begin{array}{c}\text { Stratigraphic } \\
\text { unit }\end{array}$ & $\begin{array}{l}\text { Utilized } \\
\text { feed coal }\end{array}$ & $\begin{array}{l}\text { Database } \\
\text { sample } \\
\text { prefix }\end{array}$ & $\begin{array}{c}\text { Number } \\
\text { of samples }\end{array}$ \\
\hline Alaska & $\begin{array}{l}\text { Nenana } \\
\text { Coal Province }\end{array}$ & $\begin{array}{l}\text { Middle } \\
\text { Miocene }\end{array}$ & Suntrana & Beds $3,4,6$ & $\mathrm{AK}$ & 107 \\
\hline Indiana & Illinois & Pennsylvanian & Staunton & $\begin{array}{l}50 \% \text { Staunton } / 50 \% \\
\text { unnamed Staunton }\end{array}$ & IN & 51 \\
\hline New Mexico & San Juan & Cretaceous & Fruitland & 3 unnamed beds & NM & 101 \\
\hline Ohio & Appalachian & Pennsylvanian & Monongahela & Pittsburgh & $\mathrm{OH}$ & 110 \\
\hline Wyoming & Powder River & Tertiary & $\begin{array}{l}\text { Tongue River } \\
\text { Member of } \\
\text { Fort Union }\end{array}$ & Wyodak /Anderson WY & & 80 \\
\hline
\end{tabular}

pulverized coal plants have some type of flue gas desulfurization process based on lime $(\mathrm{CaO})$ or limestone $\left(\mathrm{CaCO}_{3}\right)$ (fig. 2). For this study, plants were selected as being representative of the pulverized- coal steam power plants that utilized coal from major coal basins in the United States. The coals utilized by these plants range in age from Pennsylvanian to middle Miocene and are from the Appalachian, Illinois, San Juan, Powder River, and Nenana Basins (table 1).

\section{Generalized Power Plant Sampling Plan}

Initial discussions were held with representatives from several utilities to determine which of the pulverized coal-fired power plants would be available to participate in the study. The agreement with the participating plants was for (1) selected power plant staff to collect the necessary samples; and (2) USGS personnel to perform complete chemical, mineralogical, and petrographical analyses for all samples. It was also agreed not to mention the name of the plant, but only refer to its location by state and the basin in which the coal was mined. Samples were tailored to the design of each power plant, collected on a daily or otherwise agreed-upon schedule, and labeled with the name of the coal, type of sample (based on collection site), and date collected. Ideally, 15-25 samples of each type were collected over a 1- to 2-month time period in order for the results to be statistically evaluated.

In the first step of the sampling process, we met with plant managers and fuel engineers to discuss how 
representative samples could be collected at the selected power plant. Once a plan was developed, we toured the selected sampling points to document how the samples would be collected (figs. 3-7). Samples were collected so as to follow the flow of coal within the power plant. Once the feed coal was collected, all the other samples of CCPs were carefully coordinated to be representative of the feed coal being burned. Sample collection was timed to ensure that the various CCPs were coordinated with the feed coal. We relied on the expertise of power plant personnel to calculate how long it would take for the feed coal to reach various collection points within the plant, such as bag houses or electrostatic precipitators. All stages of the sampling schemes were optimized to minimize any adverse impacts on the power plant and (or) its staff and to also represent the best possible location available for sampling. We supplied most of the sample containers and shipping supplies to each plant. The following types of samples were collected: (See table 2 for distribution of sample types for each power plant.)

- Coal that actually goes to power plant, (for example, barge, feed, and pulverized coal, $2 \mathrm{lbs}$ or $0.907 \mathrm{~kg}$, sealed in a plastic bag)

- Fly ash (various types or mixtures depending on plant) (1 bottle-500ml)

- Economizer fly ash (if available) (1 bottle-500ml)

- Air Pre-heater ash (if available) (1 bottle-500ml)

- Bottom ash (1 bottle-500ml)

- Any anomalous constituent or property of the coal that might ultimately affect the quality

- One full bucket (5 lbs each) of fly ash for leaching or other studies

- Lime sample (if available) (1 bottle-500ml)

- Desulfurization sludge (if available) (1 bottle-500ml)

- Pyrite rejects (if available) (1 bottle-500ml)

To accomplish our goal of determining the abundance and modes of occurrence of selected elements, an extensive suite of coal-quality analyses and mineralogical, petrological, and leaching investigations were performed on all samples (both pre- and post-combustion) taken during different phases of the coal-utilization process. The purpose of this data release is to make the initial data available to the public in advance of more detailed evaluations of the data that are being prepared for future release. As new interpretations of the data are completed, they will be added to the data subset website.

\section{Sample Flow and Analytical Techniques}

Once the power plant personnel had collected the samples and returned them to the USGS the samples were sorted and sent to Geochemical Testing, Somerset, Pa., where they were divided into five splits for analysis (see fig. 8). Coal split (1) was analyzed at Geochemical Testing for proximate and ultimate analyses, forms of sulfur, calorific value, and ash-fusion temperatures determinations. Coal and CCPs split (2) and (3) were sent to the USGS Central Energy Resources Science Center Laboratories (Denver, Colo.) for chemical analysis and for XRD semi-qualitative mineral analysis. Coal split (4) was sent to the University of Kentucky, Center for Applied Energy Research for maceral and vitrinite reflectance. Coal and CCPs split (5) were stored for future studies. The split for environmental studies (leaching) is currently being analyzed and is not included in this report.

\section{Chemistry}

Determination of ash yields and analysis of major-, minor-, and trace-element contents were conducted by the USGS Central Energy Resources Science Center laboratories (Denver, Colo.). Feed coal samples were ashed at $525^{\circ} \mathrm{C}$ and (or) $750^{\circ} \mathrm{C}$ prior to analysis, with results reported on an as-determined ash basis, except for mercury, selenium, and chlorine that were analyzed on the raw, unashed coal and are reported on a whole-coal, as-determined basis. Most element concentrations were determined by inductively coupled plasma mass spectroscopy (ICPMS) (As, Be, Bi, Cd, Co, Cr, Cs, Cu, Ga, Ge, Li, Mn, Mo, Nb, Ni, Pb, Rb, Sb, Sc, Th, Tl, U, V, Y, and $\mathrm{Zr}$ ) or by inductively coupled plasma atomic emission spectroscopy (ICPAES) $\left(\mathrm{SiO}_{2}, \mathrm{Al}_{2} \mathrm{O}_{3}, \mathrm{CaO}, \mathrm{MgO}, \mathrm{Na}_{2} \mathrm{O}, \mathrm{K}_{2} \mathrm{O}\right.$, $\mathrm{Fe}_{2} \mathrm{O}_{3}, \mathrm{TiO}_{2}, \mathrm{P}_{2} \mathrm{O}_{5}, \mathrm{SO}_{3}, \mathrm{Ba}$, and $\mathrm{Sr}$ ). Mercury was analyzed by the direct mercury analyzer (DMA80), selenium was analyzed by hydride generation atomic absorption (AAnalyst200), chorine was analyzed by the total chlorine analyzer (TOX-100), and sulfur was analyzed by the LECO SC 632.

Current procedures used by USGS Central Energy Resources Science Center laboratories referenced in this report can be accessed at URL, http://energy.usgs.gov/GeochemistryGeophysics/GeochemistryLaboratories.aspx which presents all related analytical procedures, sample methodology, standard operating procedures (SOPs), publications, and quality assurance methods used by the USGS geochemical laboratory. They are also included in the appendix (Chemistry SOPs) of this report. A performance audit of the USGS Energy Resource Program (ERP) Inorganic Geochemistry Laboratory (IGL), now called the Central Energy Resources Science Center Laboratories, was conducted between August, 2003 and October, 2005. The goals were to ensure that a high level of analytical performance was maintained and to identify 


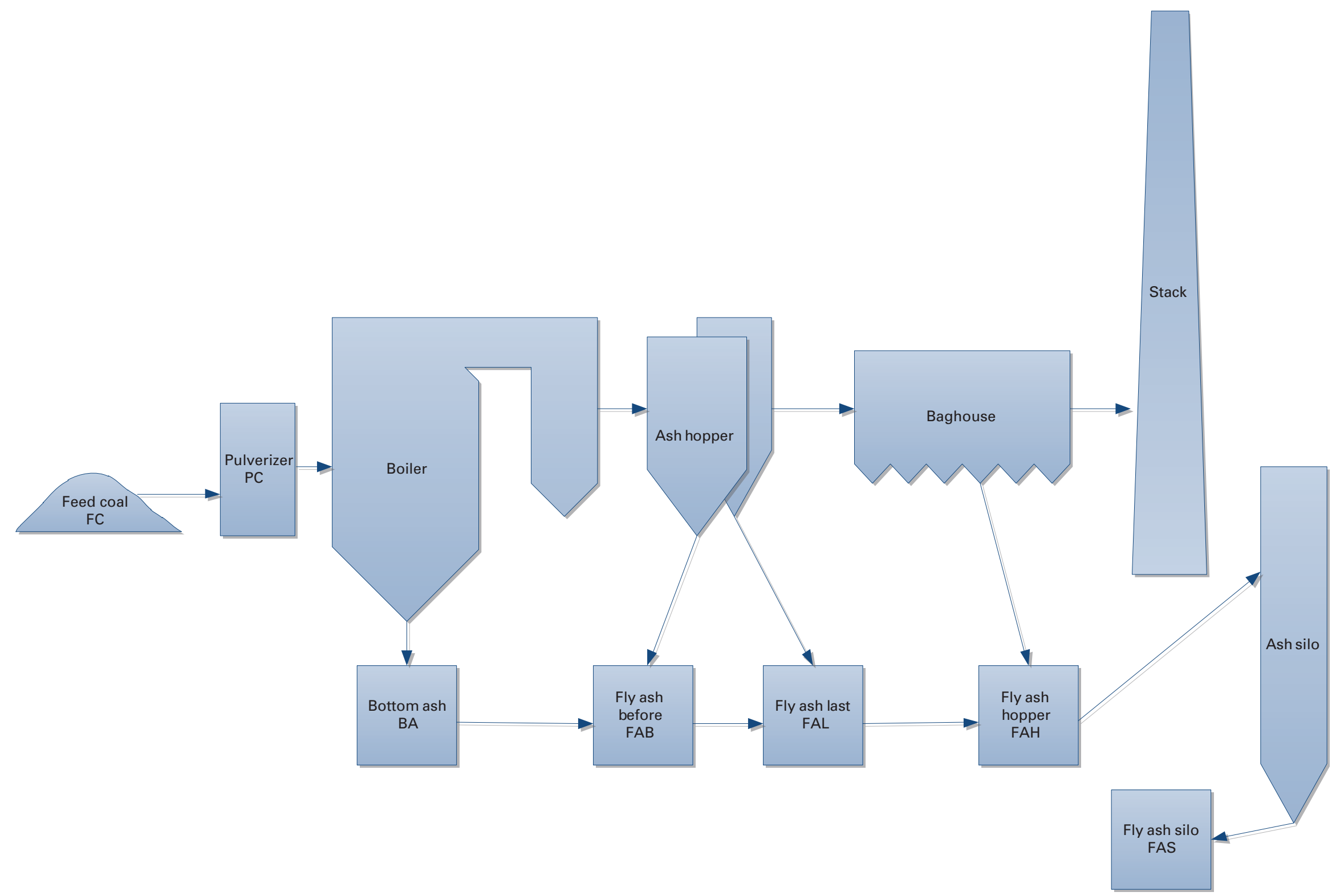

Figure 3. Diagram showing the flow of coal through the Alaska power plant and location of sample collection sites. 


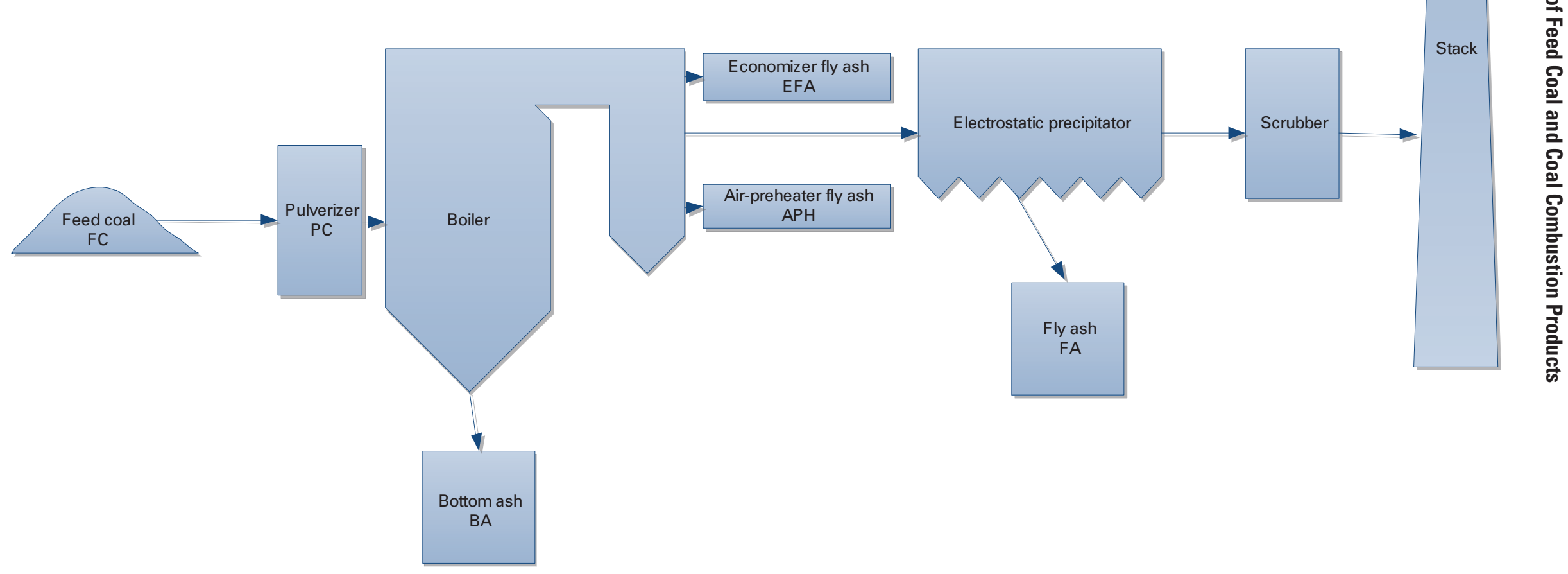

Figure 4. Diagram showing the flow of coal through the Indiana power plant and location of sample collection sites. 


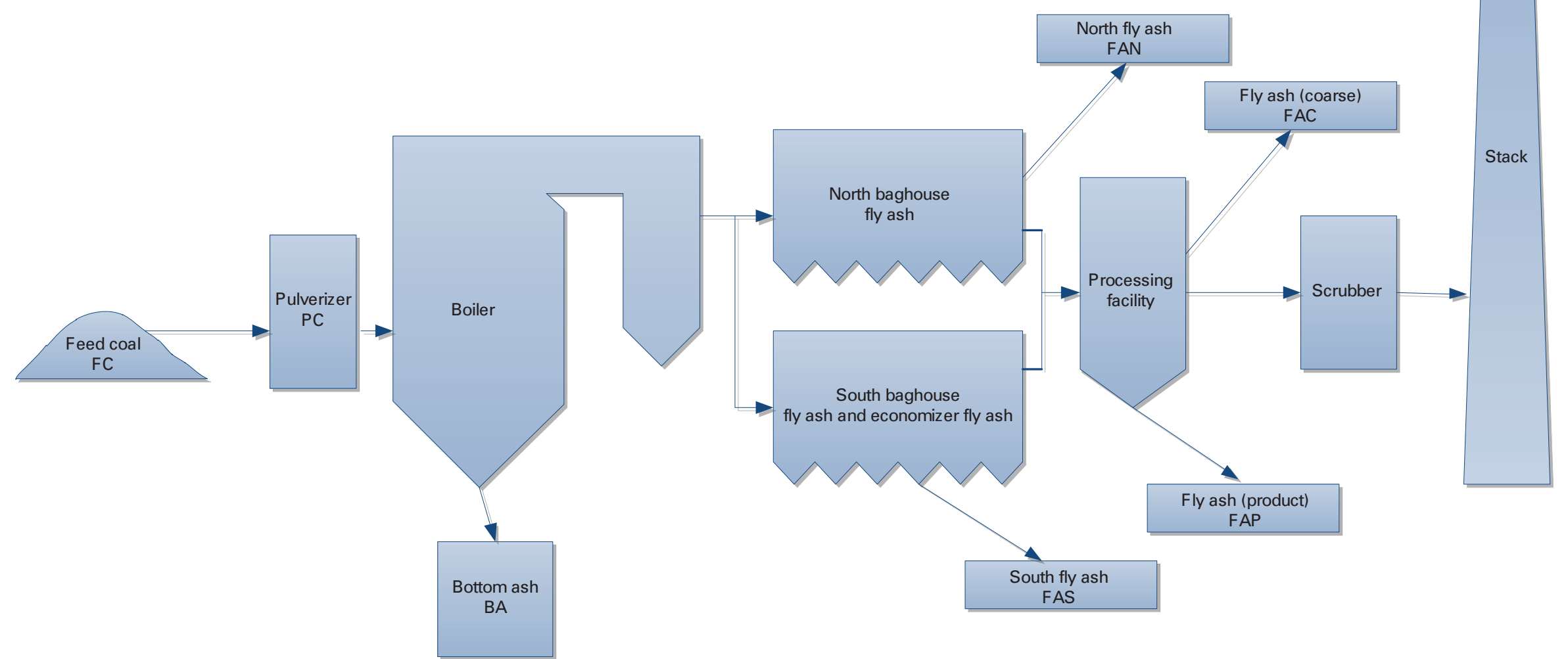

Figure 5. Diagram showing the flow of coal through the New Mexico power plant and location of sample collection sites. 


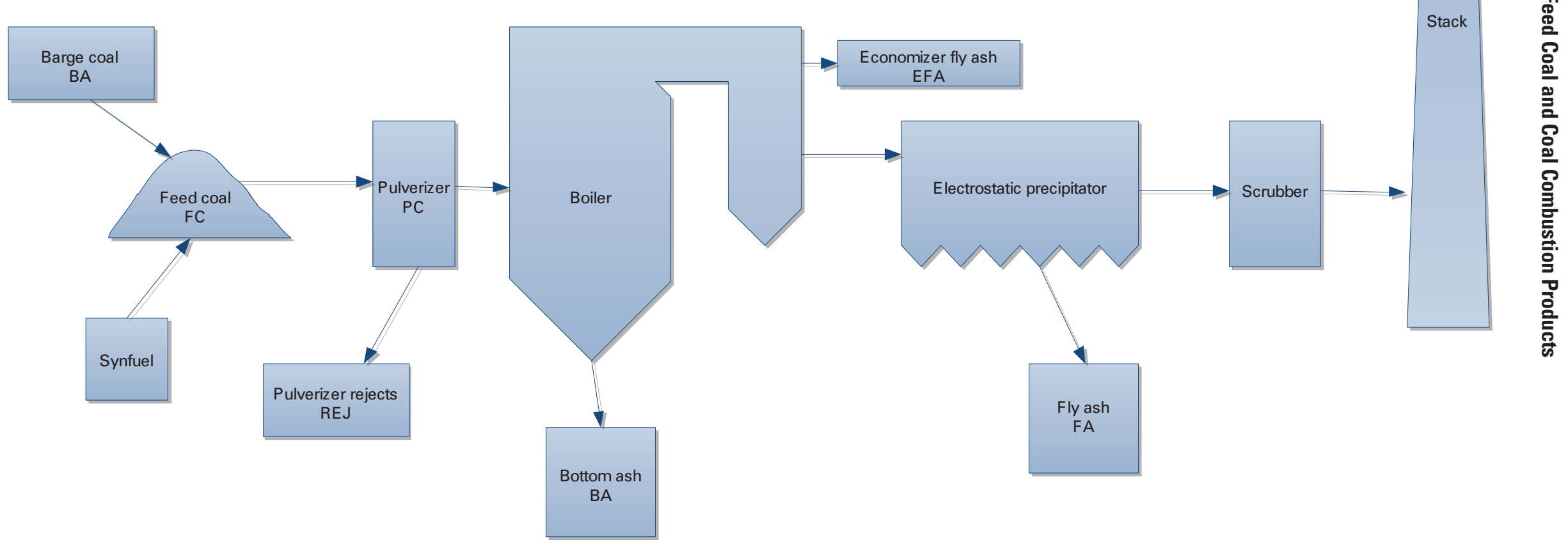

Figure 6. Diagram showing the flow of coal through the Ohio power plant and location of sample collection sites. 


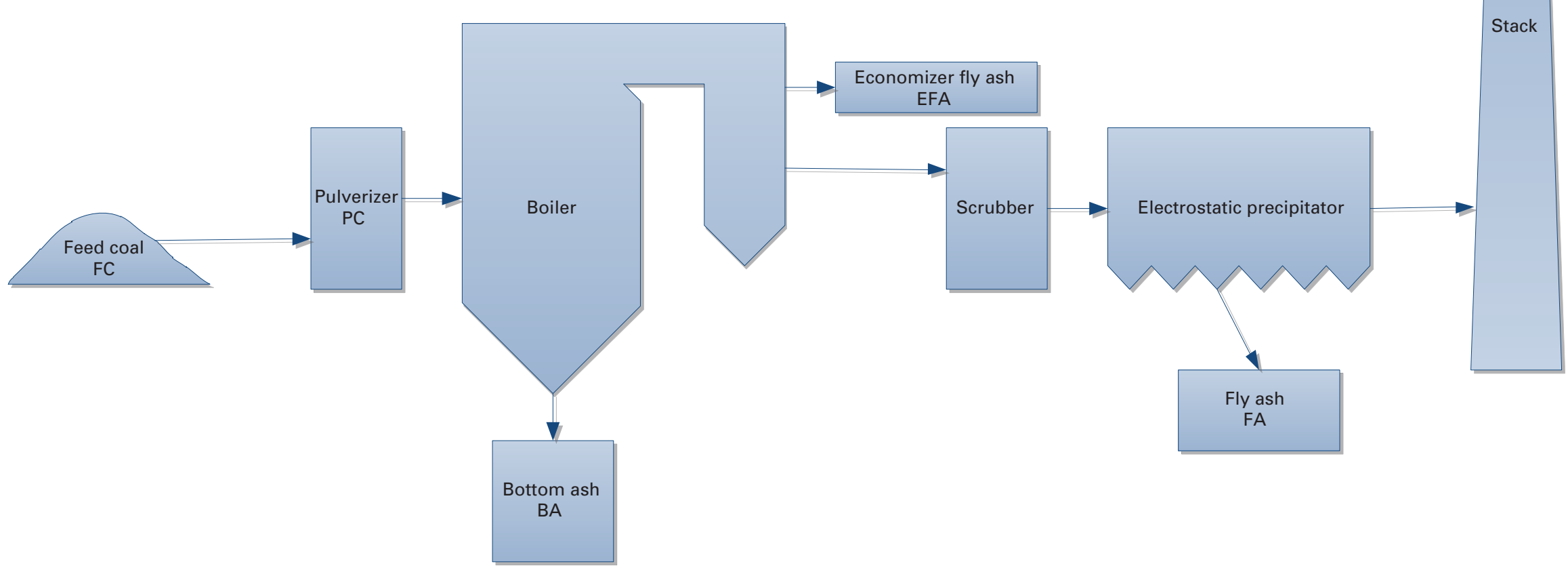

Figure 7. Diagram showing the flow of coal through the Wyoming power plant and location of sample collection sites. 
Table 2. Power plant location, type of sample, sample abbreviation, and number of samples collected for current study.

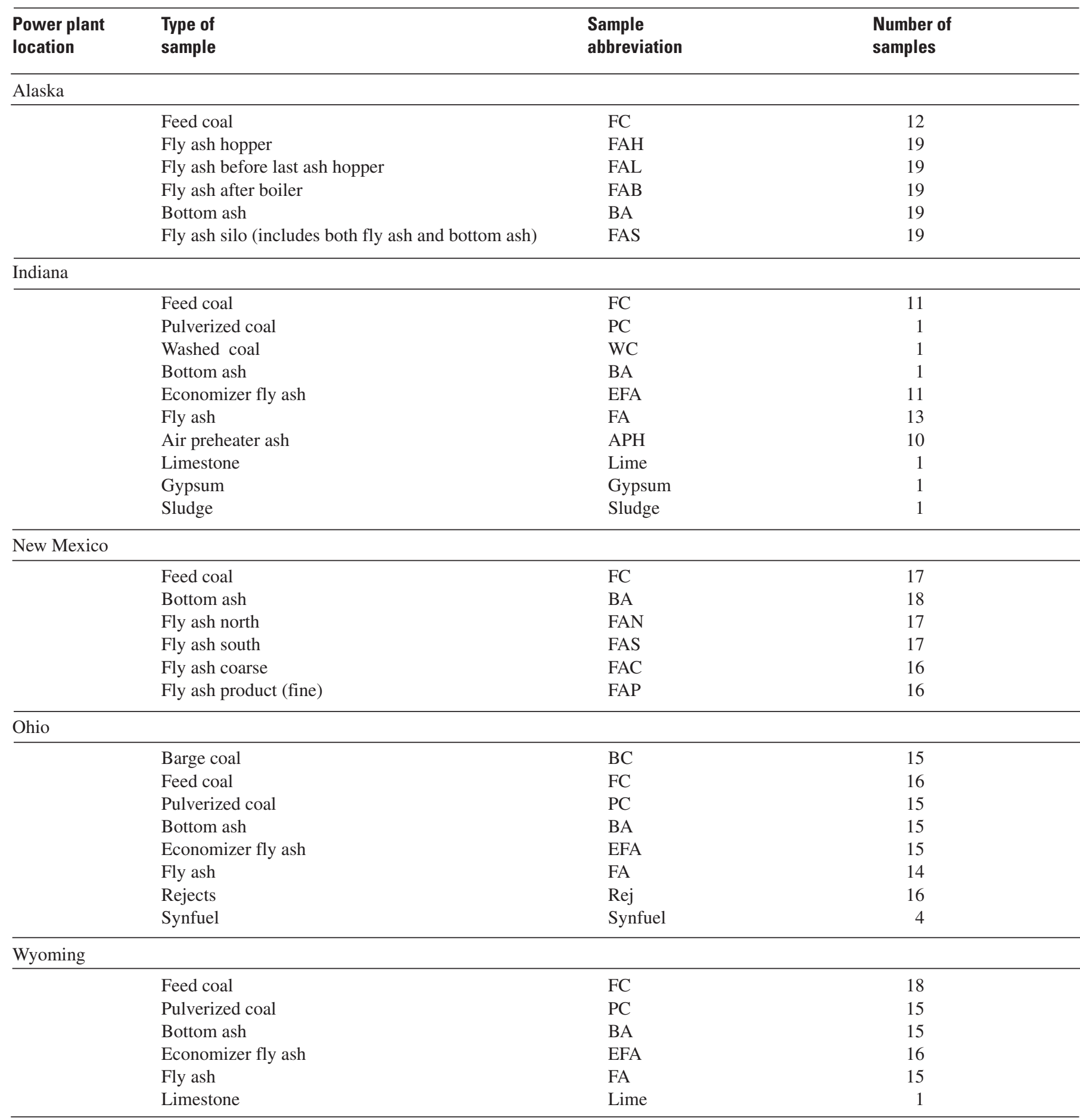

any areas that could be improved. The performance of the lab was also compared to laboratories worldwide with similar scope. The results indicated that the USGS laboratory ranked as one of the top two laboratories performing trace element analyses. Several recommendations to enhance performance on major- and minor-elemental parameters were made and implemented (Luppens and others, 2007). Because of this performance audit, a new quality assurance/quality control (QA/
QC) system was developed that now employs a three-tiered approach to QC. The first tier is analytical performance based on QA/QC samples. The second tier involves data review and blind sample programs, and the third tier is performance-evaluation studies. (See Energy Geochemistry Laboratory (EGL) procedures and QA/QC manual, ver. 1, 2 Jan 2010 at URL http://energy.usgs.gov/GeochemistryGeophysics/GeochemistryLaboratories.aspx for details.) To compare past analytical 


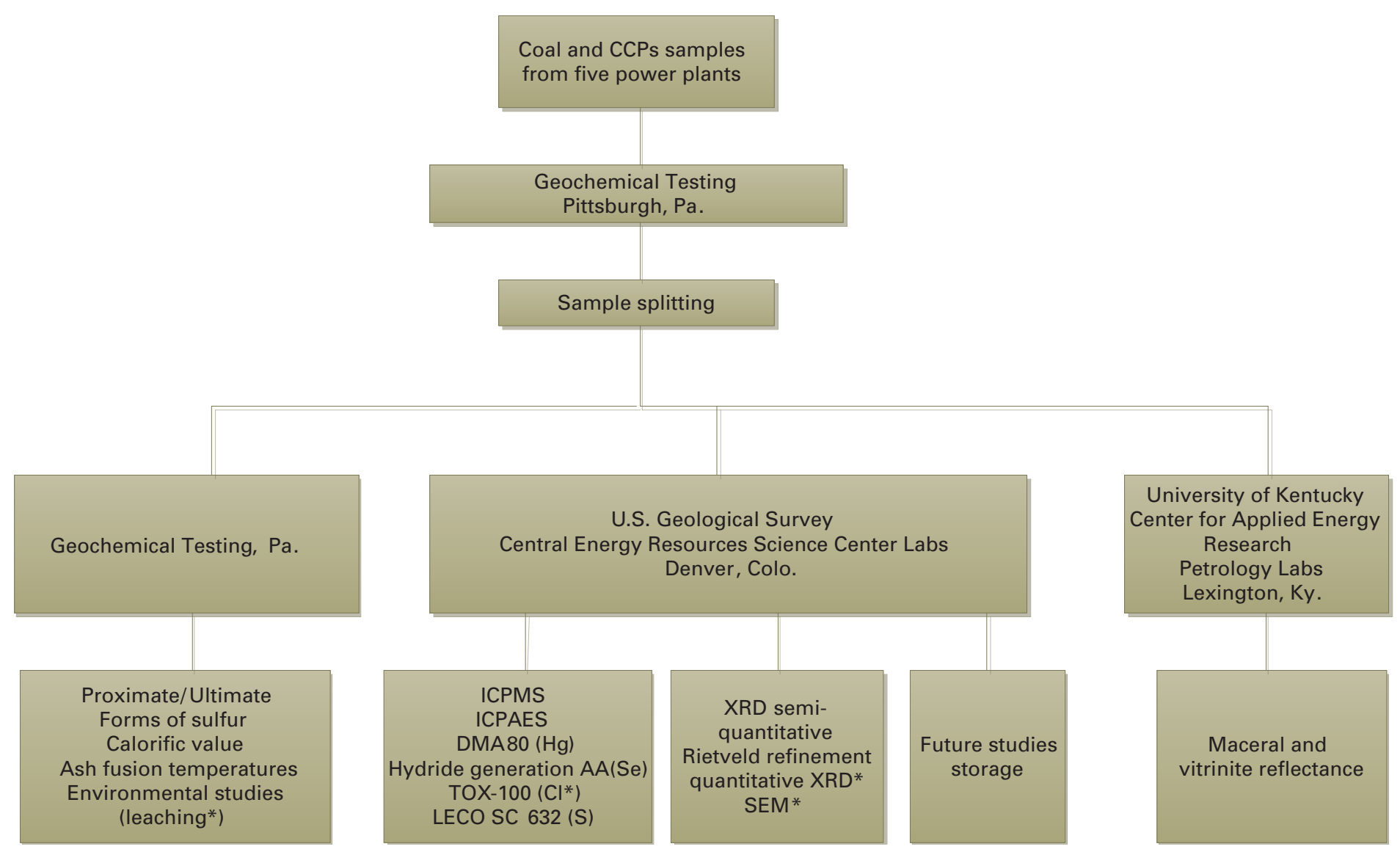

Figure 8. Diagram showing flow of samples collected at power plants and the types of analyses. [* indicates results are still in progress for selected samples and are not available in this data release.] 
methods utilized by the USGS with the methods employed in this publication, see Swanson and Huffman (1976), Baedecker (1987), Golightly and Simon (1989), and Bullock and others (2002).

All proximate and ultimate analyses and determinations of forms of sulfur and calorific values and ash-fusion temperatures were provided by Geochemical Testing, Somerset, Pa., (website can be accessed at URL http://www.geo-ces.com).

\section{Mineralogy}

\section{Sample Preparation for X-Ray Diffraction Analysis}

Successful X-ray diffraction analysis of rock, coal, and CCPs depends upon the grinding step. In the case of coal samples, the pulverization homogenizes the coal, which generally is heterogeneous, and reduces the material to small particles necessary for ashing. Splits for the rock, coal, and CCPs were reground in a SPEX ball mill for $4 \mathrm{~min}$, which reduced the powder to less than 100 micrometers $(\mu \mathrm{m})$. Wyoming, Ohio, Indiana, and New Mexico power plant materials were ball milled using stainless steel balls and a vial. The grinding vial was cleaned by grinding quartz sand between each sample and cleaned out to prevent cross contamination between samples. Alaska power plant materials (using an improved method) were micronized in 2-propanol for $4 \mathrm{~min}$ in a McCrone agate micronizing mill to facilitate both qualitative and quantitative analysis. (See Appendix, Mineral SOPs, standard operating procedures SOP1 and SOP2 for grinding of samples).

Coal samples were low temperature-ashed (LTA) (Gluskoter, 1965) in an oxygen plasma using a Branson/IPC 4155/2-plasma asher, set at 110 watts RF power, with low pressure oxygen at 0.5 torr. During ashing, the temperature was maintained below $66^{\circ} \mathrm{C}$. A five-gram aliquot of coal was evenly spread on an 8-in. diameter watch glass and placed in the LTA unit. Once each day, the samples were removed from the asher, stirred by lightly grinding in an agate mortar and pestle, and then spread back out on the watch glass and returned to the asher. This process was repeated for 5 days or until all of the coal was ashed. (See Appendix, Mineral SOPs, SOP3 for LTA of coal).

\section{XRD Qualitative Analysis}

The rock, LTA-ashed coal samples, and CCPs were backpacked (see Appendix, Mineral SOPs, SOP4) in PANalytical 27-mm ring mounts for the diffractometer's autoloader. The samples were run on a PANalytical "X'Pert Pro - MPD" $\mathrm{X}$-ray diffractometer, with a $\mathrm{Cu}$ long fine focus $\mathrm{X}$-ray tube (Ni-filtered), a Theta/Theta goniometer (Bragg-Brentano geometry), and an "X'Celerator" solid-state "strip" detector (active area set at an angle of $2.12^{\circ}$ ), with the sample stage spinner on. All samples were scanned from $5^{\circ}$ to $65^{\circ} 2 \theta$ with a $0.0167^{\circ} 2 \theta$ step size and a dwell (counting) time per step of $740 \mathrm{~s}$ (6-h total run time) for the CCPs and $125 \mathrm{~s}$ (1-h total run time) for the rock and LTA. The interpretations of the diffractograms were completed using Materials Data Inc. (MDI, 2009) "Jade" search-match software with International Center for Diffraction Data "PDF-4" (ICDD; 2009), and NIST "FIZ/ NIST Inorganic ICSD" databases (NIST, 2010).

All X-ray diffraction data were collected on a PANalytical X'Pert Pro diffractometer. PANalytical B.V. data-collection software stores the raw scan data in their own proprietary "XRDML" file format. When viewing XRDML data files, users can share data with complete traceability of produced results. For additional information see URL http://www.xrdml. com/. The XRDML files may be viewed using PANalytical's High Score or Data Viewer software packages. They can also be opened by several commercial software packages, such as Jade (Materials Data Inc., 2009) or Siroquant (Sietronics PTY Ltd., 2010). In addition there are other file converters available that will convert the XRDML format to several other manufacturer file formats, or to a comma-separated " $x, y$ " listing that may be viewed in spreadsheet programs. One such available program is the PowDLL Converter, which is available online at: http://users.uoi.gr/nkourkou/powdll.htm. (Note: any use of trade, product, or firm names is for descriptive purposes only and (or) to give meaningful examples, and does not imply any endorsement by the U.S. Government).

\section{Mineral Identification}

Minerals are identified in a peak position and intensity XRD pattern using primary reflections (greater than 50 percent intensity) and secondary reflections (greater than 15 percent intensity) as compared to the mineral reference pattern/data. For minerals present at a "major" level (greater than $25 \mathrm{wt}$ percent), numerous (more than three) primary and secondary reflections are observed in the pattern confirming the mineral's presence. For minerals present at "minor" (5-25 wt percent) or "trace" levels (less than $5 \mathrm{wt}$ percent), at least two primary reflections are observed in the pattern, as well as additional analytical data supporting the presence of the mineral, such as chemical or microscopy data or presence in other sample splits at a higher content. Clay is a unique case where a single reflection may be used to confirm its presence; however, the clay composition may not be identified without chemical and heat treatments, as well as oriented mounts for analysis. In some cases, a reflection may be observed in a pattern, but not assigned to a phase, indicating that at least one or more clay phases are present in the material.

Based on the position and character of the reflection (intensity and shape), the phase may be limited to a small group of minerals. These are typically reported as a "questionable" phase and require further analysis and data to confirm their presence. Minerals described as "intermittent," are present in some, but not all samples and will average out to 
less than 1 wt percent in the group. For most minerals, the detection limit is approximately $1 \mathrm{wt}$ percent. Highly crystalline minerals (quartz, calcite, and others) have lower detection limits and less crystalline minerals (hydrated minerals, clays, and others) have higher limits of detection.

\section{Limitations of the X-Ray Diffraction Data}

$\mathrm{X}$-ray diffraction analysis measures the crystalline portion of the sample. This does not include any amorphous inorganic or organic phase that may be present. The typical detection limit by X-ray diffraction is between 1-3 wt percent, depending on the crystallinity of the phase and interference from overlapping lines from other phases. There may be trace phases present, but they are not identified nor included in the model. Although the best fit is chosen, there almost certainly are chemical and crystallographic differences between the reference mineral and the "real-world" mineral observed in the sample that may influence the quantification.

The relative concentrations in the database are reported as major ( $>25$ percent), minor ( $5-25$ percent), trace $(<5$ percent), and intermittent $(<1$ percent). These concentrations have full meaning only if the bulk sample is essentially 100 percent crystalline. Because coal samples contain amorphous material, these relative concentrations of major, minor, and trace have to be interpreted with respect to the reported amount of amorphous material present in the bulk sample. The amorphous material can only be determined using advanced XRD methods.

\section{Petrographic Analysis of Power Plant Coals}

Coal petrography and vitrinite reflectance data (American Society for Testing and Materials, 1999b) were determined on <20-mesh sample splits prepared from the feed coal of each power plant in our study; these data are available in the database in the macerals and vitrinite tables. The samples were analyzed by the University of Kentucky Center for Applied Energy Research (http://www.caer.uky.edu/coalash/research/ petrologylab.shtml), which used petrographic microscopy to determine the abundance of major coal macerals in the feed coal. Microscopic analysis of feed coal was conducted on ground and polished epoxy-bound pellets (American Society for Testing and Materials, 1999a). The final polishing step used $0.05-\mu \mathrm{m}$ alumina slurry, and examination was conducted with reflected-light, oil-immersion optics at a final magnification of 500x. Petrographic nomenclature follows the outline of ICCP $(1998,2001)$ and American Society for Testing and Materials (American Society for Testing and Materials, 1999c).

In the Access Data Series.mdb macerals table, the maceral content is reported in percent in the first column and data are reported as the percent mineral-free maceral (MFM) count in the second column. Trace amount $(\mathrm{T})$ means that the maceral was identified, but not landed on, in the course of the point counting; "other" refers to minerals dominated by quartz, and, "silicates" refer to clays. All photographs of macerals were produced using oil-immersion, reflectedlight optics with a 50x objective. In the vitrinite database table, $R_{\text {max }}$ is the mean maximum reflectance measured in oil, $R_{\text {random }}$ is the same as $R_{\text {mean }}$, and Std Dev is the standard deviation. The v's are the percentage of the reflectance values reading within a 0.1 percent range, so that $\mathrm{v} 2$ represents percent of values from $0.20-0.29$; $v 3$ represents percent of values from $0.30-0.39$; v4 represents percent of values from $0.40-0.49$; v5 represents percent of values from $0.50-059$; v6 represents percent of values from $0.60-0.69$; v7 represents percent of values from $0.70-0.79$; v8 represents percent of values from $0.80-0.89$; and $\mathrm{v} 9$ represents percent of values from $0.90-0.99$. For additional information please see the USGS Photomicrograph Atlas at http://energy.usgs.gov/Coal/ OrganicPetrology/PhotomicrographAtlas/tabid/366/Agg1080_ SelectTab/1/Default.aspx.

\section{Summary of Data}

All data in this report can be accessed through the Data Series.mdb. However, we have also generated statistical-summary data tables of the chemistry and summary tables of the mineralogical data, as well as selected X-ray diffractograms of coal and CCPs from each power plant studied.

\section{Chemistry}

Tables 1-8 (Appendix, Chemistry Summary Tables) include descriptive statistics including number of samples, mean, median, range, and standard deviation of proximate and ultimate analyses; calorific value; forms-of-sulfur analyses; and ash-fusion temperatures of all coal samples analyzed. All values in these tables are reported on an as-received basis and are in percent except calorific value (Btu/lb) and ash-fusion temperatures $\left({ }^{\circ} \mathrm{F}\right)$. Tables 9-14 (Alaska), 15-18 (Indiana), 19-24 (New Mexico), 25-31 (Ohio), and 32-36 (Wyoming) (Appendix, Chemistry Summary Tables) include descriptive statistics of number of samples, mean, median, range, and standard deviation of ash yield; and contents of selected major, minor, and trace elements for all coal and CCPs that were analyzed. In these tables, all analyses are in percent or parts per million and are reported on an as-determined ash basis except for mercury $(\mathrm{Hg})$ and selenium (Se), which were analyzed on a whole-coal basis. Sulfur (S) is reported in percent and ND means not determined. L means less than value shown. Leaders (---) indicate statistics could not be calculated owing to an insufficient number of analyses above the lower detection limit.

A common problem in statistical summaries of traceelement data arises when the element values are below the limits of analytical detection. This results in a censored distribution. These values, called non-detects, may be zero or 
larger than zero, but are below the limits of analytical detection and should not be reported as zero values (U.S. Environmental Protection Agency, 2002). Where data for analyzed elements contained non-detects, the summary statistics for these samples were calculated using the Kaplan-Meier method as outlined by Helsel (2005a, p. 63). These calculations were performed using the NADA library within the free R program (R Development Core Team, 2009), which is available at URL http://www.R-project.org . These calculations were only run for elements that contained values below the detection limit. If over half of the samples were not detected (ND), then the median value becomes not available (NA). For additional information on non-detects, see Helsel (1990, 2005b).

\section{Mineralogy}

Tables 37-41 (Appendix, Mineral Summary Tables) include mineral name, composition, and relative concentration as determined by X-ray diffraction for coal and CCPs. In these highly amorphous samples, the relative concentrations of the mineral matter are grouped into: major $(\mathrm{Ma})>25 \mathrm{wt}$ percent, minor (mi) ranging from 5-25 wt percent, trace $(\mathrm{Tr})<5 \mathrm{wt}$ percent, and intermittent (int), which means that the minerals identified are not present in all samples and are identified about $<1$ wt percent of the time. All these data are based on the total crystalline mineral content only. For simplification the summaries are categorized into silicates, oxides, carbonates, sulfides, sulfates, sulfites, and other minerals. These groups are also color coded (low to high, with red being high), so that the individual power plant mineralogy can easily be compared.

Also included are selected X-ray diffractograms of coal and CCPs that represent for each power plant, the mineral compositional changes from feed coal into the various CCPs. These diffractograms were completed using Materials Data Inc. (MDI, 2009) "Jade" search-match software with International Center for Diffraction Data "PDF-4" (ICDD, 2009), and NIST "FIZ/NIST Inorganic ICSD” databases (NIST, 2010). Representative samples from each power plant are available in the "Selected XRD diffractogram" directory (Alaska, figs. 1-6; Indiana, figs. 7-13; New Mexico, figs. 14-19; Ohio, figs. 20-26; Wyoming, figs. 27-31) in order to demonstrate the mineral identification process in the samples. These plots show the original X-ray diffraction scan (black trace) and have also been enhanced to help in the identification of minerals present in the sample. A background (red line) under the scan is used solely to display identification sticks for each mineral observed in the pattern and does not represent the true instrument background for the scan. At the top right, the minerals identified in the scan are listed and color coded. For each mineral, a reference card from a crystal structure database was used to generate colored "sticks" representing reflections, both location and intensity, for a particular mineral in the scan range. Thus, each mineral has numerous reflections in the plot and many of these reflections overlap with one another. In addition to the color coding, the first letter of each mineral name is shown above the stick. This plot can be viewed at higher zoom level to more clearly show the mineral assignments. At the top left of each file, the power plant, sample number, and sample type are identified. The sample number can be referenced to the actual raw XRD pattern in the XRDML directory. This sample number can then be used to view the actual X-ray scan stored in the digital database using appropriate software.

\section{Selected Coal Utilization References}

This selected bibliography attempts to encompass the most relevant literature that will help serve as a foundation on which to appropriately understand the complexities of coal utilization. Since the early 1970s, the USGS has been involved in evaluations of data collected from various coal utilization and power plant-related studies. The publications in this bibliography cover the last 50+ years and include many past, unique, and current studies involving coal utilization. Subject material ranges from utilization of coal to disposal of CCPs, with topics on new technology and regulations. These references were compiled as a source of associated material for this Data Series and can be viewed in the References pamphlet on the CD.

\section{Description of Power Plant Data Series}

\section{Overview}

This power plant Data Series (DS) contains analytical data from samples taken at five U.S. power plants. The results of the analyses have been combined into a Microsoft Access database. The following sections describe the table design and navigation of the DS.

\section{Table Design}

The database table design flows from least specific to most specific in the following order: JOBS -> SAMPLES -> $<$ analysis results>

The JOBS table contains fields that give summaries of where samples were collected, basin where the coal was mined, and the age of the stratigraphic unit. The SAMPLES table contains additional information about the individual samples, such as locality where collected and links to images associated with the samples. The <analysis results $>$ tables have been named according to the analysis performed on the individual samples. The data fields within each analysis results table are named according to the analysis parameters 
and reporting units, and use the following naming convention: Parameter_Units.

The X-Ray Diffraction (XRD) table is designed differently than the other analysis tables. The "XRD" table provides a list of minerals identified in each sample, the Powder Diffraction File ID (PDF ID) number, the Chemical Composition, and the Relative Quantitative value. Each sample contains multiple records, which is dependent on the number of minerals identified in the sample.

Three tables containing images have been included in the database, which have the image files linked to fields in the tables. The Petrology Images table lists the sample number, name of the image file, a description of the image, and the path to the linked image file. Clicking on the link will open the file. The Petrology image files are stored as JPG files and are viewable by a variety of applications. The XRD Patterns table contains XRD patterns (with the peaks marked with the identified mineralogy), sample number, description, and path to the linked image file. A PDF viewer application such as "Adobe Acrobat Reader" is required to view these images. The SEM Images table lists the sample number, name of the image file, a description of the image, and the path to the linked image file. Clicking on the link will open the file. The SEM image files are stored as JPG or PDF files and are viewable by a variety of applications.

The results from each of the analysis results tables have been combined into a single table named "AllData." The "AllData" table includes everything except the XRD results. To see the XRD results, open the XRD table.

\section{How to Access Data}

Open the Power plant Data Series.mdb database. A form named "Main Menu" will be displayed if the macro security settings in the user's Microsoft Access application have been set to Low, or if user accepts the security warning displayed when the database is opened. If macros have been disabled, the data can be accessed by selecting the Tables object from the Objects menu bar on the left side of the database window. This will display the table objects created for this database. Each table is named according to the analysis data stored in that specific table. Select the desired table to view the data in the datasheet view.

Queries for each of the power plants have been included in the database and can be run from the "Main Menu" form or from the Query object that can be accessed from the Objects menu bar on the left side of the database window. A detailed description of each analysis is on the USGS Central Energy Resources Science Center's website. http://energy.usgs.gov/ GeochemistryGeophysics/GeochemistryLaboratories.aspx.

Documentation describing each of the tables and fields in this database is in the Excel file named "Power plant Data Series Documentation," which is in the Data and Documentation directory. (Note: Any use of trade, product, or firm names is for descriptive purposes only and (or) to give meaningful examples, and does not imply any endorsement by the U.S. Government). 


\section{Summary of Data Collected and Included in this Data Series}

Data from five different coal-fired power plants are divided into eight directories (fig. 9 shows location of the eight directories on the $\mathrm{CD}$ ) which includes:

1. The Appendix directory contains the Chemistry Summary Tables (tables 1-36), Mineralogy Summary Tables (tables 37-41), Chemistry SOPs, and Mineral SOPs.

2. The Data Series Data and Documentation directory contains the Data Series.mdb, Power Plant Data Series Documentation (.doc and .xls files), and power plant collection schemes. If the user does not have Microsoft Access, the raw data tables can be viewed in a Microsoft Excel file named "Data Series Tables.xls". However the user will not have the functionality of Microsoft Access.

3. The Data Series Manuscript directory contains the main manuscript file, tables, and figures that are referenced in the manuscript. This manuscript presents an overview of why and how samples were collected, and gives details on the various analytical methods presented in this Data Series.

4. The Petrology Images directory contains image files from selected power plants. The file names describe the identified macerals. The JPG files of these images are also included in the Petrology Image table in the database. To view the images in the Petrology Images table, double-click on "Package" in the Petrology Image field. The image should open in the default JPG file viewer.

\section{The Selected References (References pamphlet)} directory contains relevant power plant references that will help in understanding the complexities of coal utilization.

6. The Selected XRD Diffractograms directory contains representative X-ray diffractograms (PDF file format) for each power plant. The PDF files are also included in the XRD Patterns table in the database. To view the diffractograms in the XRD Patterns table, double-click on "Adobe Acrobat Document" in the XRD Pattern field. The diffractogram image should open in the default PDF viewer.

7. The SEM Images directory contains selected SEM images from several power plants. An explanation of each photo can be found in the file named "Figure Captions.doc." The SEM Images table contains links to the JPG or PDF image files. To view the images from the SEM Images table, click on the hyperlink in the "path" field. The image should open in the default JPG or PDF file viewer.

8. The XRDML Files directory contains the raw data files from the XRD analysis that can be viewed using PANalytical's proprietary software, or other freeware applications that are listed in the DS documentation. 


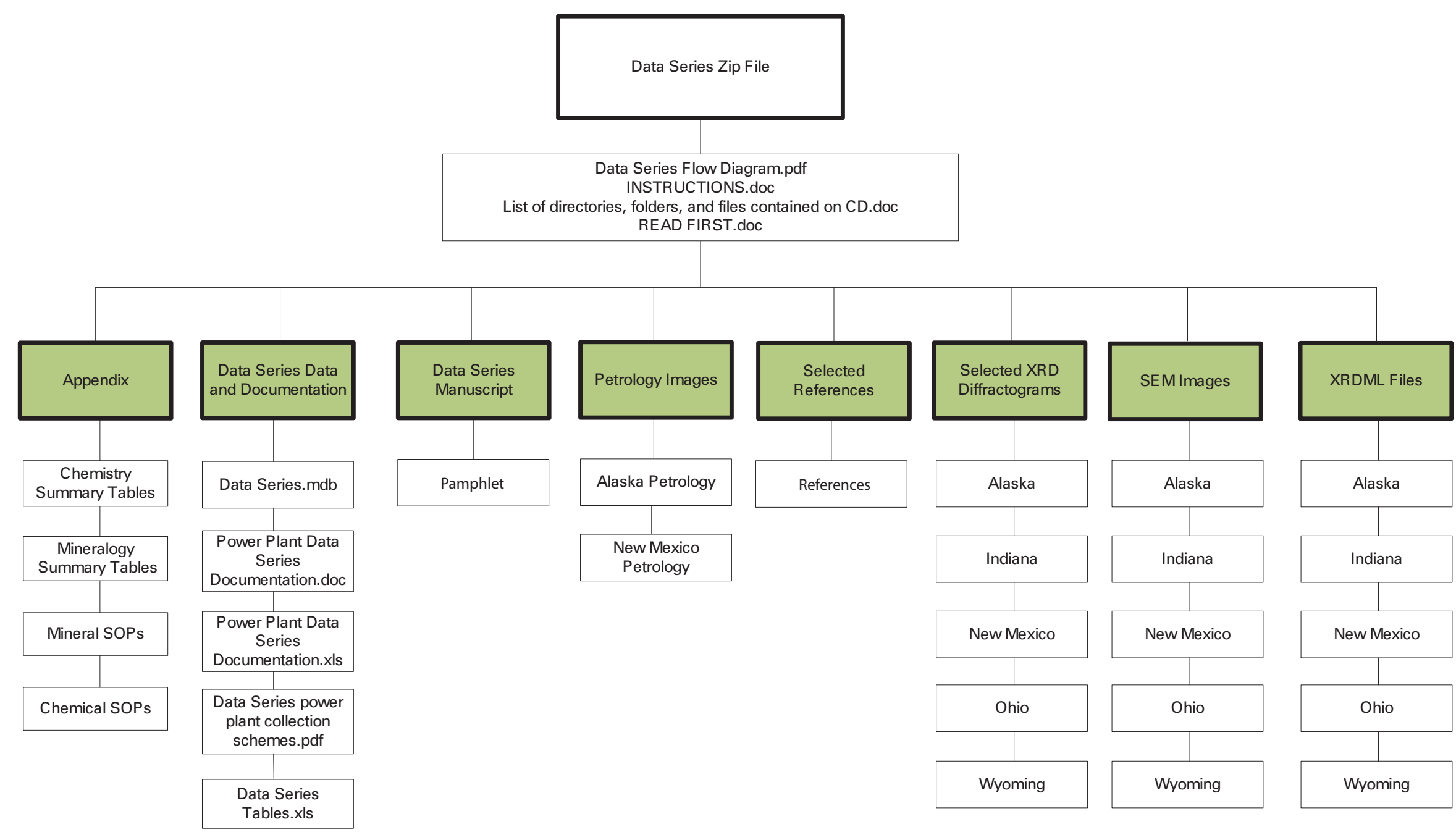

Figure 9. File structure of Data Series "Geochemical Database of Feed Coal and Coal Combustion Products (CCPs) from five power plants in the United States: Consisting of Major-, Minor-, and Trace-Element Contents, Proximate and Ultimate Analyses, Forms of Sulfur, Calorific Values, Ash Fusion Temperatures, Mineralogy, Petrological Data, and Selected Coal Utilization References." 


\section{Contacts}

Ronald H. Affolter affolter@usgs.gov (Data Series lead, chemistry, Wyoming, Indiana, and Alaska power plants)

Steve Groves sgroves@usgs.gov (database)

William J. Betterton wbettert@usgs.gov (mineralogy)

William Benzel wbenzel@usgs.gov (mineralogy)

Kelly L. Conrad klconrad@usgs.gov (references)

Sharon M. Swanson smswanson@usgs.gov (New Mexico and Ohio power plants)

Leslie F. Ruppert lruppert@usgs.gov (Ohio power plant)

James G. Clough jim.clough@alaska.gov (Alaska power plant)

Harvey E. Belkin hbelkin@usgs.gov (SEM for Alaska and Wyoming)

Allan Kolker akolker@usgs.gov (SEM for Indiana and Ohio)

James C. Hower hower@ caer.uky.edu (petrology)

\section{Acknowledgments}

We wish to thank personnel of the five power plants that participated in this study, for their help in providing timely access to their facilities, and for facilitating the sampling process by collecting an assortment of coal and coal combustion products (CCPs) that we requested of each individual plant. We benefited greatly from their assistance to make this study possible. We also thank Dave Goss, former president of the American Coal Ash Association (ACAA), for his encouragement of this study, and for his aid in helping us to choose and to work with the various plants. The authors thank Lee Osmonson and Sue Tewalt for their editorial review of the report. We also acknowledge the following for their contributions of the indicated data:

\section{List of Other Contributors}

Petrology-J.D. Stucker, Jordan W. Drew, Antonia E. Hansen, and Rachel S. Hatch Students from the University of Kentucky, Center for Applied Energy Research, Lexington, Ky.

Chemistry-Jamey McCord, Khanh Doan, Lisa Brazeau, and Toni Kennedy from the USGS lab, Denver Colo.

Proximate/Ultimate analyses, forms of sulfur, calorific value, and ash fusion temperatures-Geochemical Testing, 2005 N. Center Ave., Somerset, PA 15501

Statistics-Summary of analysis of non-detects by Nicholas J. Geboy, USGS, Reston, Va.

SEM-New Mexico and Ohio power plant additional images by Kevin B. Jones, USGS, Reston, Va.

\section{References Cited}

American Society for Testing and Materials (ASTM), 1999a, Standard practice for preparing coal samples for microscopical analysis by reflected light, D2797-85, in 1999 Annual Book of ASTM Standards; Petroleum products, lubricants, and fossil fuels, sec. 5, v. 05.05-Gaseous fuels, coal, and coke: Philadelphia, Pa., ASTM, p. 295-298.

American Society for Testing and Materials (ASTM), 1999b, Standard test method for microscopical determination of the reflectance of vitrinite in a polished specimen of coal, D2798-97, in 1999 Annual Book of ASTM Standards; Petroleum products, lubricants, and fossil fuels, sect. 5, v. 05.05-Gaseous fuels, coal, and coke: Philadelphia, Pa., ASTM, p. 299-303.

American Society for Testing and Materials (ASTM), 1999c, Standard test method for microscopical determination of volume percent of physical components of coal, D2799-98a, in 1999 Annual Book of ASTM Standards; Petroleum products, lubricants, and fossil fuels, sect. 5, v. 05.05-Gaseous fuels, coal, and coke: Philadelphia, Pa., ASTM, p. 304-307.

Baedecker, P.A., ed., 1987, Methods for geochemical analysis: U.S. Geological Survey Bulletin 1700, p. 1n1-1n3.

Bullock, J.H., Jr., Cathcart, J.D., and Betterton, J.D., 2002, Analytical methods utilized by the United States Geological Survey for the analysis of coal and coal combustion byproducts: U.S. Geological Survey Open File Report 02-389, $16 \mathrm{p}$.

Golightly, D.W., and Simon, F.O., 1989, Methods for sampling and inorganic analysis of coal: U.S. Geological Survey Bulletin 1823, $72 \mathrm{p}$

Gluskoter, H.J., 1965, Electric low-temperature ashing of bituminous coal: Fuel, v. 44, p. 285-291.

Goodarzi, F., 2002, Mineralogy, elemental composition and modes of occurrence of elements in Canadian feed coals: Fuel, v. 81, p. 1199-1213.

Goodarzi, F., 2005, Petrology of subbituminous feed coal as a guide to the capture of mercury by fly ash-Influence of depositional environment: International Journal of Coal Geology, v. 61, no. 1-2, p. 1-12.

Grossman, S.L., Nathan, Y., and Mathews, A., 1988, The mineralogy and chemistry of coal ash generated by the Hadera M.D. Power Station: Journal of Coal Quality, v. 7, no. 1, p. 22-26.

Helsel, D.R. 1990, Less than obvious-statistical treatment of data below the detection limit: Environmental Science and Technology, v. 24, p. 1766-1774. 
Helsel, D.R., 2005a, Nondetects and Data Analysis: Statistics for Censored Environmental Data (Statistics in Practice): Wiley-Interscience, Hoboken, N.J., 250 p

Helsel, D.R., 2005b, More Than Obvious: Better methods for interpreting nondetect data: Environmental Science and Technology, v. 39, p. 419A-423A.

International Center for Diffraction Data, PDF-4+, 2009, 12 Campus Boulevard, Newtown Square, Pa. 19073, available at URL http://www.icdd.com.

International Committee for Coal and Organic Petrology, 1998, The new vitrinite classification (ICCP System 1994): Fuel 77, 349-358.

International Committee for Coal and Organic Petrology, 2001, New inertinite classification (ICCP system 1994): Fuel 80, 459-471.

Karayı̆̆ııt, A.I., Onacak, T., Gayer, R.A., and Goldsmith, S., 2001, Mineralogy and geochemistry of feed coals and their combustion residues from the Cayirhan Power Plant, Ankara, Turkey: Applied Geochemistry, v. 16, p. 911-919.

Luppens, J.A., Janke, L.G., McCord, J.D., Bullock, J.H., Brazeau, Lisa, and Affolter, R.H., 2007, Performance audit of the U.S. Geological Survey, Energy Resource Program Inorganic Geochemistry Laboratory: U.S. Geological Survey Open-File Report 2007-1136, 93 p.

Materials Data Inc., 2009, 1224 Concannon Blvd., Livermore, Calif. 94550, available at URL http://www.materialsdata. com/

National Institute of Standards and Technology, 2010, NIST Standard Reference Database 84, 100 Bureau Drive, Stop 2300, Gaithersburg, MD 20899, available at URL http:// www.nist.gov/ts/msd/srd/nist84.cfm .

R Development Core Team, 2009, R: A language and environment for statistical computing, R Foundation for Statistical Computing, Vienna, Austria, ISBN 3-900051-07-0, available at URL http://www.R-project.org.

Sheetz, B.E., 2004, Chemistry and mineralogy of coal fly ash: Basis for beneficial use, in State Regulation of Coal Combustion By-Product Placement at Mine Sites: A Technical Interactive Forum: Harrisburg, Pa., U.S. Department of the Interior, Office of Surface Mining Reclamation and Enforcement, Mid-Continent Region, Alton, Ill., and Coal Research Center, Carbondale, Southern Illinois University, p. 35-42.

Sietronics Pty Limited, 2010, Unit 3/32 Walder St., P.O. Box 3066, Belconnen ACT 2616, available at URL: http://www. sietronics.com.au/
Skorupska, N.M., and Marsh, H., 1989, The importance of petrographic characterization of coal for combustion Processes, in Institute of Energy Conference on Applied Energy Research, Swansea, United Kingdom: Bristol, United Kingdom, Hilger, p. 161-181.

Skorupska, N.M., 1993, Coal specifications - Impact on power station performance: London, United Kingdom, International Energy Agency [IEA] Coal Research, Report IEACR/52, 120 p.

Swanson, V.E., and Huffman, Claude, Jr., 1976, Guideline for sample collecting and analytical methods used in the U.S. Geological Survey for determining chemical composition of coal: U.S. Geological Survey Circular 735, 11 p.

U.S. Environmental Protection Agency, 2002, Calculating upper confidence limits for exposure point concentrations at hazardous waste sites: Office of Emergency and Remedial Response, Washington, D.C., December 2002. OSWER 9285, 6-10, 29p.

U.S. Geological Survey, 2001, Coal combustion products: U.S. Geological Survey Fact Sheet FS-076-01, 4 p.

U.S. Geological Survey, 2002, Characterization and modes of occurrence of elements in feed coal and coal combustion products; an integrated approach: U.S. Geological Survey Fact Sheet FS-0038-02, 4 p. 